Article

\title{
Assessment of Final Space Cooling Consumption in the European Transportation Sector
}

\author{
Giulio Quaglini ${ }^{1} \mathbb{D}$, Simon Pezzutto ${ }^{1, *} \mathbb{C}$, Andrea Grotto ${ }^{1,2}$ and Eric Wilczynski ${ }^{1}$ \\ 1 Institute for Renewable Energy, European Academy of Bolzano (EURAC Research), Viale Druso 1, \\ 39100 Bolzano, Italy; giulio.quaglini@eurac.edu (G.Q.); andrea.grotto@eurac.edu (A.G.); \\ eric.wilczynski@eurac.edu (E.W.) \\ 2 Catalonia Energy Research Institute (IREC), Jardins de les Dones de Negre 1, $2^{\mathrm{a}} \mathrm{pl}$., \\ 08930 Sant Adria del Besos, Spain \\ * Correspondence: simon.pezzutto@eurac.edu; Tel.: +39-0471-055-622
}

check for updates

Citation: Quaglini, G.; Pezzutto, S.; Grotto, A.; Wilczynski, E. Assessment of Final Space Cooling Consumption in the European Transportation Sector. Sustainability 2022, 14, 1491. https://doi.org/10.3390/su14031491

Academic Editor: Enrique

Rosales-Asensio

Received: 15 December 2021

Accepted: 25 January 2022

Published: 27 January 2022

Publisher's Note: MDPI stays neutral with regard to jurisdictional claims in published maps and institutional affiliations.

Copyright: (c) 2022 by the authors. Licensee MDPI, Basel, Switzerland. This article is an open access article distributed under the terms and conditions of the Creative Commons Attribution (CC BY) license (https:// creativecommons.org/licenses/by/ $4.0 /)$.

\begin{abstract}
The current study aims to investigate one of the most underexplored energy fields in scientific research, i.e., final energy consumption (FEC) of space cooling (SC) in the European (EU27+UK) transportation sector with 2019 as a baseline. The fundamentals of this study include a comprehensive literature review as well as the creation of a dataset characterized by completeness and reliability. Different essential input parameters have been investigated and the encountered data and information gaps have been filled. The transportation sector has been broken down into three main categories, namely, light, medium, and heavy vehicles. Throughout the EU27+UK, the number of vehicles, equivalent full load hours (EFLHs), system power capacities, and their related energy efficiency levels have been collected. The collected data and information have been computed and the EU27+UK FEC for space cooling in the transportation sector resulted in more than $125 \mathrm{TWh} /$ year. It is worth underlining that the light vehicles category accounted for the majority of the total FEC, followed by the medium and heavy vehicle categories, respectively.
\end{abstract}

Keywords: space cooling; transport; Europe; energy consumption; assessment

\section{Introduction}

It has been decades since the European Union (EU) focused its efforts on achieving ambitious climate and energy goals. Particularly, the EU 2020 objectives included a 20\% improvement in energy efficiency as well as a $20 \%$ increase in the share of renewable energy sources (RES) and a $20 \%$ reduction in greenhouse gas (GHG) emissions compared with 1990 levels by the year 2020 .

Significant support to achieve the above-mentioned goals came from the Energy Efficiency Directive (EED), set in 2002 and revisited in 2018 when it became the revised Energy Efficiency Directive (EED II), with an increase in energy efficiency improvements from 20 to $32.5 \%$ [1-3]. Moreover, in 2018 the Renewable Energy Directive (RED-2009/28/EC) was updated to the revised Renewable Energy Directive (RED II), which concerns the 2021-2030 timeframe and increases the target share of RES required by the EU Member States (MSs) from $20 \%$ to $32.5 \%$ [4]. Lastly, in 2018, the EU's GHG emissions were targeted to be reduced by $55 \%$ until 2030 in addition to plans for Europe to be the first continent to achieve a net-zero target by 2050 [3].

According to the above-mentioned acts, EU scientific experts noticed that, in 2018, GHG emissions reduced by 23\% from 1990 levels and that the implementation of the EDD II could lead to lower utility bills and more efficient energy use throughout all the sectors. In addition, the RED II could push the EU to generate more than $80 \%$ of energy from RES while reducing the external market's dependence on oil and gas $(O \& G)$ suppliers, therefore increasing climate change resilience. Particularly, the current EU's energy production from RES requires an increase of up to 2.5 times above the present level [2]. 
The RED II entails different energy sectors. In 2018, the heating and cooling (H\&C) energy sector was responsible for the greatest portion of the primary energy consumption (PEC) [5]. In more detail, the RED II requires EU MSs to raise the RES share in the H\&C sector by an average of 1.3 percentage points (ppt) from 2021 to 2030 [6]. The EU's total PEC, in 2016 accounted for around 1600 Mtoe/y, of which about half ( $800 \mathrm{Mtoe} / \mathrm{y})$ is accounted by the $\mathrm{H} \& \mathrm{C}$ sector-which includes space heating (SH) and space cooling (SC) for buildings comfort, the residential and tertiary sectors, domestic hot water (DHW), and process cooling (PC) for the industry sector. The transportation sector is responsible for around $490 \mathrm{Mtoe} / \mathrm{y}$, while the electricity sector is responsible for around $310 \mathrm{Mtoe} / \mathrm{y}$, accounting for the remaining EU's total PEC [7].

The main topic of the current study is referred to as "space cooling", which refers to the removal of heat from the indoor air of an enclosed space (e.g., buildings) resulting in a lower temperature and/or a phase change for thermal comfort of the occupants. In addition, the typical set-points of an indoor air temperature are between 20 and $30^{\circ} \mathrm{C}$. Overall, the action of removing heat requires an external energy input to transfer thermal energy and it occurs against the second law of thermodynamics [8]. Moreover, it is important to state that the current study excludes "refrigeration" applications in the transportation sector since its primary function is to store perishable materials at certain temperatures [9]. In contrast, this study is focused on space cooling for human comfort purposes.

Furthermore, it is worth mentioning that in the current work, the terms "cabin cooling", and "human comfort cooling" are referred to as space cooling.

A significant increase in demand for SC compared to space heating (SH) is expected in the upcoming year [4]. A constant increment over the past thirty years has been observed for SC in terms of final energy consumption (FEC), as well as in terms of sales volume of SC equipment $[9,10]$. Overall, the SC needs throughout all sectors are expected to increase significantly by 2030 and 2050 [11,12]. Several reasons drive this SC trend, including global warming, population growth, welfare increase, urbanization (which leads towards hotter building surfaces), larger glazing areas (especially in the tertiary sector), and data centers that require significant cooling [2,12-14].

In terms of SC equipment, almost the entire SC technologies market (99\%) is comprised of vapour-compression technology (VC), which is driven by electricity [7-13]. The remaining part of the market is composed of Thermally Driven Heat Pumps (TDHPs) technology [15]. Vapour compression technologies can be found in the residential as well as the service and process sectors both for SC and PC applications.

It is important to state that the SC sector has not been investigated much in scientific research compared with the $\mathrm{SH}$ sector [11]. Poor information and data can be found on SC with regard to residential, service, and industrial parts, and even fewer data and information are available on SC in the transportation sector, which is the focus of this study.

The present study aims to assess the European final energy consumption (FEC) for SC related to human comfort in the vehicle's cabin in the private and public transportation sectors. Numerous vehicles have been selected as subjects of this research, such as cars, trucks, tractors, buses, aircraft, ships, and trains. It is worth noting that the term FEC significantly differs from useful energy demand (UED) [16]. Notably, the latter is considered as the net heat which needs to be removed from the vehicle's cabin to be cooled while the FEC is related to the energy input of the cooling system installed in transports.

Once again, it is important to state that limited data can be found in the scientific literature on this topic and there have been significant difficulties in data and information collection due to the lack of resources and restrictions. A certain reference year has not been settled on for this study regarding the high-quality dataset creation; however, 2019 has been selected as the most adequate baseline since most of the collected data and information came from this year.

One of the most essential parts of this research is to generate a dataset on the transportation sector to assess the FEC for SC in the EU27+UK. To accomplish this, three main aspects were considered to ensure the accuracy, completeness, and reliability of the present work. 
- Data inventory;

- Data reliability;

- Data definition and comparability.

\subsection{Data Inventory}

The work presented in the current section includes the scouting and listing of all existing data and information on the topic. Since the research was carried out at the European level, it offers advantages in terms of quantity of data and information thanks to the extension of the territory. A concise literature review methodology has been applied by scouting online through Google Scholar only scientific sources such as databases, peerreviewed scientific journal papers, and reports. Different online datasets (e.g., ECMWF [17], EUROSTAT [18], UNECE [19], IATA [20], ENERGY PLUS [21]) were consulted. Notably, from the above-mentioned sources, historical meteorological data have been scouted, essential for the estimation of the air-conditioning usage behavior of the population, as well as the European road traffic data divided by vehicle types, and energy consumption simulation to possibly compare the space cooling usage in buildings with the transportation sector. Moreover, reports (e.g., ACEA 2019 [22], ICCT 2019 [23], European Commission 2018 [24]), and articles (CEMA 2019 [25]) were examined to understand the composition of the European transportation sector in detail, in terms of numbers of vehicles, shares of different fuel types, yearly driven distance, and different years of registrations for each vehicle category.

Additionally, several journal papers (e.g., Johnson et al., 2002 [26], Farrington et al., 2000 [27], Vaghela et al., 2014 [28], Paffumi et al., 2018 [29], Weng et al., 2019 [30], Ozkan et al., 2006 [31], Zulkifli et al., 2015 [32], Jong et al., 2016 [33], Mebarki et al., 2013 [34], Achaichia et al., 2011 [35], Santos et al., 2014 [36]) were fundamental in the source-by-source scouting phase. Vaghela et al., 2014 investigated the load calculation of automobile air-conditioning systems with mathematical models for space cooling transfer phenomena of the vehicle cabin [28]. Although the latter has been significant for understanding the light and medium vehicle sector's space cooling system capacities and efficiencies, no results at EU27+UK have been presented. In addition, Weng et al., 2019 studied the design and implementation of a lowenergy-consumption air-conditioning control system for smart vehicles proposing a better energy-efficient cabin architecture [30]. Lastly, Zulkifli et al. in 2015 pointed out that, in their study, the electric compressor resulted in lower fuel consumption and better coefficient of performance compared to the conventional compressor [32]. Notably, throughout the literature review of scientific journals, topics such as the investigation of loads of the electric compressor on the automotive air-conditioning system, as well as on trucks, airplanes, buses, and trains, were scouted and marked as essential to understand air-conditioning systems efficiency and peak capacities. Moreover, several sources mentioned above include research on space cooling in buildings, important for data comparison. In addition, in 2002, the National Renewable Energy Laboratory (NREL), conducted a study on assessing the fuel consumption for the whole U.S. vehicle market by considering a thermal comfortbased approach founded on laboratory simulations [27]. The abovementioned work has been evaluated in the first phase of this study in which the most suitable approach could have been taken into consideration. Eventually, after the evaluation, a top-down approach seemed the best route for the present work without involving laboratory simulations, and by constructing a solid and reliable database for the calculation phase.

Furthermore, concerning the several sources mentioned above, it was necessary to properly provide the author/s, access, title, time references, and terms of usage to access, comprehend, and utilize the scouted data and information. The main intention was to appropriately represent the collected data and information in a comprehensible method. As already mentioned in Section 1, the SC sector entirely lacks any type of energy data, and therefore contextual information and a representation of the collected material for the current study are beneficial for any further in-depth research of this sector. 


\subsection{Data Reliability}

Once the data inventory was created as presented in Section 1.1. Data inventory, a deeper analysis of the collected sources was conducted to assess their related reliability. It is important to state that several gaps were identified throughout the scouting phase, some of which were filled through assumptions and estimations (e.g., million vehicles kilometer per year-MWKm/y, threshold temperature for air-conditioning-AC). The remaining uncertainties have been excluded since they could have led to large-scale computational errors. It is important to state that although some data and information were initially investigated at the very first embryonal phase of the study (e.g., million vehicles kilometer per year-MWKm/y), they have not been further processed due to a lack of data during the collection phase. Therefore, a different approach that eventually involved dissimilar types of information has been considered (please see Section 2.)

It is worth mentioning that all of the data and information collected for cooling in the transport sector (i.e., the quantity and the categories of vehicles per country, the installed capacities of the cooling technology per vehicle, category, and country, the equivalent fullload hours (EFLHs) of the SC systems, and the cooling degree days) have been statistically assessed (Section 2-Materials and Methods details the methodology) [37].

\subsection{Data definition and Comparability}

Since the collected data and information for this study were not entirely comparable, adjustments of gaps and discrepancies were required. Particularly, several differences in terms of methods, measurements, specifications, time references, and assumptions were identified from the sources [38].

Data were collected from the datasets mentioned in Section 1.1. Data inventory and the most recent records have been utilized by identifying 2019 as the reference year for the current research. In contrast, collected data that were older than 10 years have not been classified as significant and therefore excluded.

Overall, the current text concerns the country-by-country final energy consumption of cooling for human comfort in the EU27+UK transportation sector. The reference year of this study is 2019 .

The text structure entails Section 2, which involves the detailed gathering of data and information which helped us to produce the material utilized in the study, and the methods which consist of the procedures created to compute the results. Section 3 presents the results with tables and figures. Section 4 discusses the computed results presented in the previous-mentioned sections. Section 5 points out the summary of the outcome of the study with potential further developments.

\section{Materials and Methods}

One of the most critical aspects of this study-the assessment of FEC of SC for human comfort in the EU27+UK transportation sector-consisted of a breakdown of the SC technology types which are applied in the transportation sector and their key parameters. Moreover, data and information concerning the weather forecast per EU27+UK country were necessary to assess the cooling season in which the SC systems are mainly switched on. A critical parameter, such as the European stock of vehicles, was required, as well.

Hence, the following data per cooling technology and EU27+UK country have been investigated:

- Number of vehicles

- $\quad$ Equivalent full load hours (EFLHs)

- Cooling system power capacity

- Energy efficiency level

Furthermore, it is important to state that, in the present work, the EU27+UK stock of vehicles has been divided into transport categories since different types of cooling equipment are present in different types of vehicles (i.e., the capacity installed of the SC system of a car is different from the one of a train). 
Notably, vehicles are sorted into different categories based on a weight scale. Particularly, vehicles weighing less than $3500 \mathrm{~kg}$ have been considered light, while medium vehicles weighing more than $3500 \mathrm{~kg}$ were categorized medium. Lastly, aircrafts, ships, and trains were reported in the heavy category [22].

Overall, the main categories under which the EU27+UK has been grouped are:

1 Light vehicles (Passenger cars and vans-weight less than $3500 \mathrm{~kg}$ )

2 Medium vehicles (Buses, Coaches, Trucks, Tractors-weight more than $3500 \mathrm{~kg}$ )

3 Heavy vehicles (Ships, Trains, Aircrafts)

Several key sources have been scouted throughout the data collection phase in this research. Notably, the European Centre for Medium-Range Weather Forecasts (ECMFW), Eurostat (which produce European statistics in partnership with National Statistical Institutes in the EU MSs), Energy Plus Weather Data (funded by the U.S. Department of Energy'sDOE, the Building Technologies Office-BTO, and managed by the National Renewable Energy Laboratory-NREL) were essential providers of data on weather forecasts such as temperatures, humidity, and cooling degree days (CDDs) across the EU27+UK [15,16,19].

The abovementioned information was essential for the input of the EFLHs calculation of each SC technology installed in each vehicle that makes up the EU27+UK transports sector. Particularly, the term EFLHs describes the intended degree of utilization of a technical system. The term is largely used in the energy-production plants' field by referring to the time for which a system needs to operate at its nominal power (capacity-kW) to convert the same amount of electrical work in a certain period [39]. In this study, the term is referred to as the yearly number of hours in which the cooling system of a vehicle is running for human comfort.

Moreover, the thermal balance point of the vehicle, which has been assumed as the average outdoor temperature below which SC is not needed and above which heating is not required, was assumed as $20^{\circ} \mathrm{C}$ [27]. The reference temperature was assessed by considering the reference temperature in Report 1 of the Renewable Cooling under the "Revised Renewable Energy Directive ENER/C1/2018-493" [27]. Although the latter is focused on the building sector, the space-cooling load is considered linearly dependent on the outdoor temperature as it has been assumed in the transportation sector in this study.

In addition, in the case of maximum temperature encountered throughout the year, the SC system of the vehicle has been assumed to be switched on at $100 \%$ capacity for the whole SC season. Lastly, since the study carried out included a top-down approach, no vehicle occupancy simulations have been conducted.

The following equation (Equation (1)) has been utilized to compute the yearly number of EFLHs in the EU27+UK transportation sector:

$$
\text { EFLHs }=\sum_{i, \text { season }} \frac{T i-20}{T m a x-20}, T i>20
$$

where:

- $T_{i}$ is a certain hourly outdoor temperature

- $T_{\max }$ is the maximum outdoor temperature reached in the whole cooling season

In addition, the Copernicus Global Land Service and the Meteonorm software were essential to retrieve weather files that contain key parameters such as $T_{\text {max }}$ and $T_{i}$ by climate zones and EU27+UK countries [38-41]. The CDDs at the NUTS2 level were retrieved from the public repositories of the H2020 HotMaps project [42]. The latter, defined as the number of days where the temperature is above $20^{\circ} \mathrm{C}$, were important in determining the cooling season length [43].

According to the main transport categories mentioned above, the ELHs calculation method presented mainly entails the light and medium vehicles groups while aircraft, grouped under heavy vehicles, have been subjected to a different EFLHs computation methodology. 
The SC of the air transport sector has been subjected to certain considerations since, at high altitudes (e.g., 11,000 $\mathrm{m}$ for a typical commercial flight), the external temperatures drop to negative $51^{\circ} \mathrm{C}$ [44]. Therefore, in this study, the time at which the SC system is turned on for human comfort in the aircraft cabin has been assumed as $1 \mathrm{~h}$. This time includes preparation tasks (ordering, cleaning, baggage handling), which is about $30 \mathrm{~min}$. After this phase, the pilots are permitted to open the gate, and it takes another $30 \mathrm{~min}$ to embark all passengers [45]. To calculate the EFLHs for the aircraft sector, the SC time of the aircraft cabin has been computed with the cooling season length, as well as the number of flights throughout the whole EU27+UK [20].

Following the transport categories mentioned above, the SC system power capacity, the energy efficiency levels, and the stock of vehicles have been investigated:

1. The light vehicles category was divided into subcategories by dividing cars and the light commercial categories. Particularly, the latter refers to motor vehicles of up to 3.5 tons mainly used for the carriage of goods. According to the European Automobile Manufacturer Association (ACEA), the number of vehicles in use in the EU27+UK, with 2019 as a baseline, has been collected [22]. Particularly the collected data entails light vehicles by different fuel types, such as petrol, diesel, hybrid electric, batteryelectric, plug-in hybrid, and LPC + natural gas. An essential study, conducted by NREL, by Farrington et al., 2000 [27] on how the fuel economy impacts the APU (auxiliary power unit). In the current study, for simplicity reasons, the auxiliary power loads have been assumed as having $3 \mathrm{~kW}$ average capacity peak among the different vehicles fuel types.

2. The medium vehicles category has been partitioned into buses, trucks, and tractors. Concerning buses and trucks, the ACEA has been appointed as the most complete source to retrieve the stock in the EU27+UK in 2019 by fuel type [22]. Regarding the tractors sector, EUROSTAT provided the stock of vehicles at the NUTS2 level [46]. Data gaps have been filled in different EU27+UK countries by regressions according to CEMA information [25]. Moreover, regarding the medium vehicles SC system types, the Integrated air-conditioning (AC) and Rooftop AC systems have been identified as the most common throughout the sector [47]. Notably, the most recurrent SC peak power capacity lies in ranges between 3.5 and $8.5 \mathrm{~kW}$ for Rooftop AC and between 4 and $9.6 \mathrm{~kW}$ for Integrated AC in the buses and tractors category. Regarding trucks, the Rooftop AC with a peak capacity of $1.6 \mathrm{~kW}$ has been appointed [47].

3. The heavy vehicles category has been broken down into trains, ships, and aircrafts. The train sector was investigated in terms of several locomotives and railcars, by the source of power $[48,49]$. Regressions have been computed to fill the lack of data for different EU27+UK countries. In terms of ship's stock data collection, it is important to state that the number of vessels collected in the study involves the ownership EU27+UK MS and the operational flags are already counted [50]. The key sources have been the Department of Transport of GOV UK and IHS $[45,46]$. Regarding the aircraft sector, EUROSTAT provided the number of aircraft of each EU27+UK MS by age whose sum generate the stock [51]. Concerning the training sector, Rooftop AC systems with a range between 20 and $35 \mathrm{~kW}$ of capacity have been appointed as the most common cooling technology mounted on both locomotives and railcars [52]. Lugo-Villaba et al., 2017 broke down the ship's air-conditioning sector by investigating energy savings of the air handling unit (AHU) of which the maximum SC capacity has been assumed to be around $392 \mathrm{~kW}$ [53]. Lastly, regarding the aircraft sector, the air-cycle machine, which also pressurizes the cabin and is powered by the APU, has been appointed with a maximum SC capacity of $56 \mathrm{~kW}[50,51,54,55]$.

Regarding the SC system efficiency, it is important to state that a significant lack of information has been encountered. Almost no numerical data were retrieved during the scouting phase. Therefore, in this case, Dittman et al., 2017 has been an essential reference for this study [56]. Notably, the work proposed a breakdown of VC technologies which mainly entailed SC in the buildings sector. In addition, seasonal performance metrics have 
been retrieved from Regulations (EU) 626/2011 [57], (EU) 206/2012 [58] for AC systems with peak capacities below $12 \mathrm{~kW}$, and lastly from Regulation (EU) 2281/2016 [59] for larger AC systems. Furthermore, efficiency parameters, such as the seasonal energy efficiency ratio (SEER), have been collected from the previously mentioned sources and a comparative analysis has been carried out between the SC building and transport sectors (e.g., Small splits-2.5 kW with a SEER of 4.3 mainly applied in the building sector have been compared with the APU of cars in the light vehicle segment, addressed with $3 \mathrm{~kW}$ of cooling capacity). It is worth to mention that no different energy efficiency levels related to different vehicles productions years have been considered.

Following the wide data and information collection conducted above, meshes and numerical assessments have been made. Data outside the range of minus or plus one standard deviation were excluded from the study (according to Section 1.3). The remaining values have been numerically assessed to construct a solid mean.

Once more, it is worth stating that the information-gathering process strictly involved technical literature As mentioned in Section 1, the FEC is related to the energy input of the cooling system installed on the vehicles, therefore a work input $\left(W_{\text {input }}\right)$ has been computed by dividing the space cooling system power capacity to their respective energy efficiency levels per vehicle category and EU27+UK MS. Finally, the FEC of SC in the EU27+UK transportation sector has been assessed using Equation (2) below, which involved the quantity (number- $N r_{\text {vehicles }}$ ) multiplied by their relative EFLHs (time- $T$ ) and its work input $\left(W_{\text {input }}\right)$ per EU27+UK MS.

$$
F E C_{\text {space cooling }}=N r_{\text {vehicles }} * T_{\text {equivalent full load hours }} * W_{\text {input }}
$$

where:

- $N r_{\text {vehicles }}$ is the number of vehicles of a certain category

- $T_{\text {equivalent full load hours is the equivalent full load hours }}$

- $W_{\text {input }}$ is the work input of the space cooling system, intended as the fraction of the system power capacity and its respective energy efficiency level

The following Section 3 presents the outcomes of the above-mentioned calculation with facts and figures broken down into the three main vehicle categories.

\section{Results}

\subsection{Light Vehicles}

Concerning the light vehicle group, the two main transport types that were considered were cars and light commercial vehicles (up to 3.5 tonnes of weight).

Figure 1 below presents the outcome of the FEC for space cooling in the light vehicle category.

As is evident, the largest energy-consuming sub-category is of cars, with an overall FEC in the EU27+UK of about $90 \mathrm{TWh} / \mathrm{y}$, while light commercial vehicles generate an FEC in EU27+UK of around $26 \mathrm{TWh} / \mathrm{y}$. Regarding the car segment, the histograms show that Italy is the most energy-consuming MS, with about $24 \mathrm{TWh} / \mathrm{y}$, followed by Spain with around $20 \mathrm{TWh} / \mathrm{y}$, and France and Germany with more than $10 \mathrm{Twh} / \mathrm{y}$, respectively. The remaining MSs has only minor values. Concerning the light commercial segment, Spain presented the highest values with more than $8 \mathrm{TWh} / \mathrm{y}$, followed by Italy with more than $5 \mathrm{TWh} / \mathrm{y}$, and France with $4 \mathrm{TWh} / \mathrm{y}$. Lesser values are shown for the remaining MSs.

According to the ACEA database mentioned in Section 2 of the current study, the largest numbers in terms of cars are detained by MSs such as Germany, Italy, France, Spain, and Poland, while in terms of commercial light vehicles France, Italy, Spain, Germany, and Poland result to register the highest values [22]. Apart from Poland, in which its EFLHs resulted in lower values compared to the above-mentioned MSs, the light vehicle results are in line and related to the quantities of registered vehicles presented in the report of ACEA [22]. Further details are presented in Tables A1 and A2 in the Appendix A. 


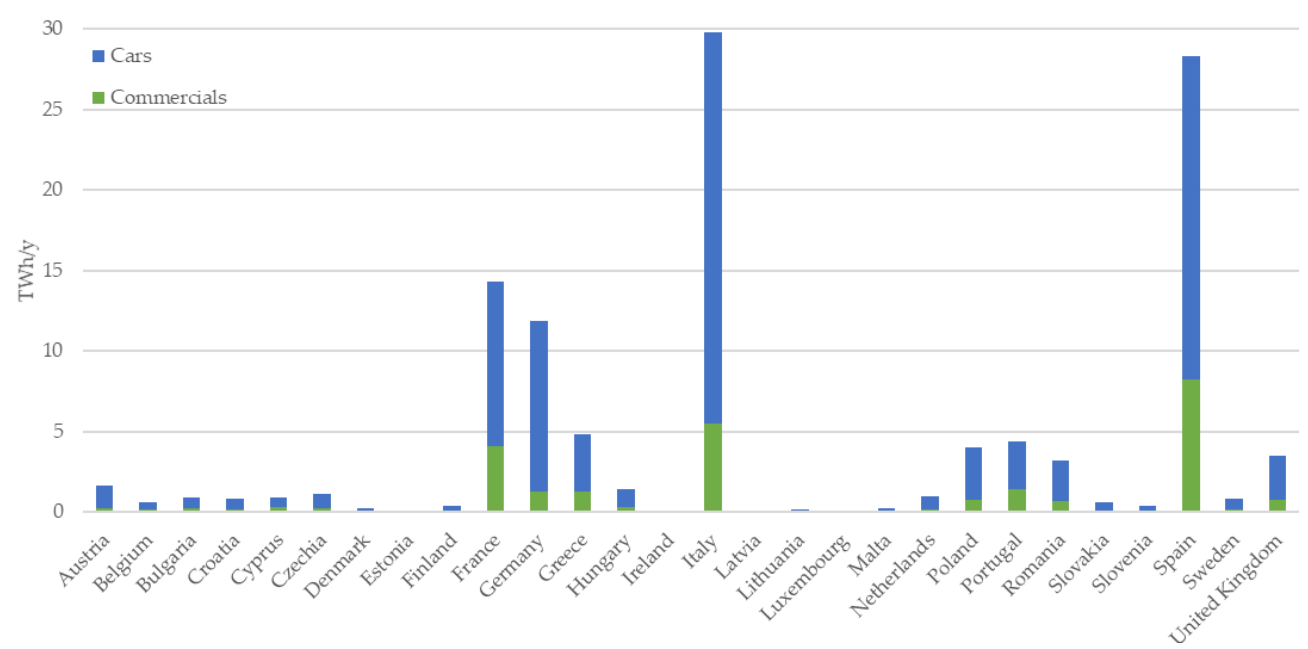

Figure 1. Final energy consumption for space cooling in the light vehicles category for the EU27+UK-the reference year 2019.

\subsection{Medium Vehicles}

The medium vehicle category was broken down into the following three main segments: trucks, tractors, and buses.

Figure 2 below highlights the main results of the FEC for space cooling in the medium vehicle category.

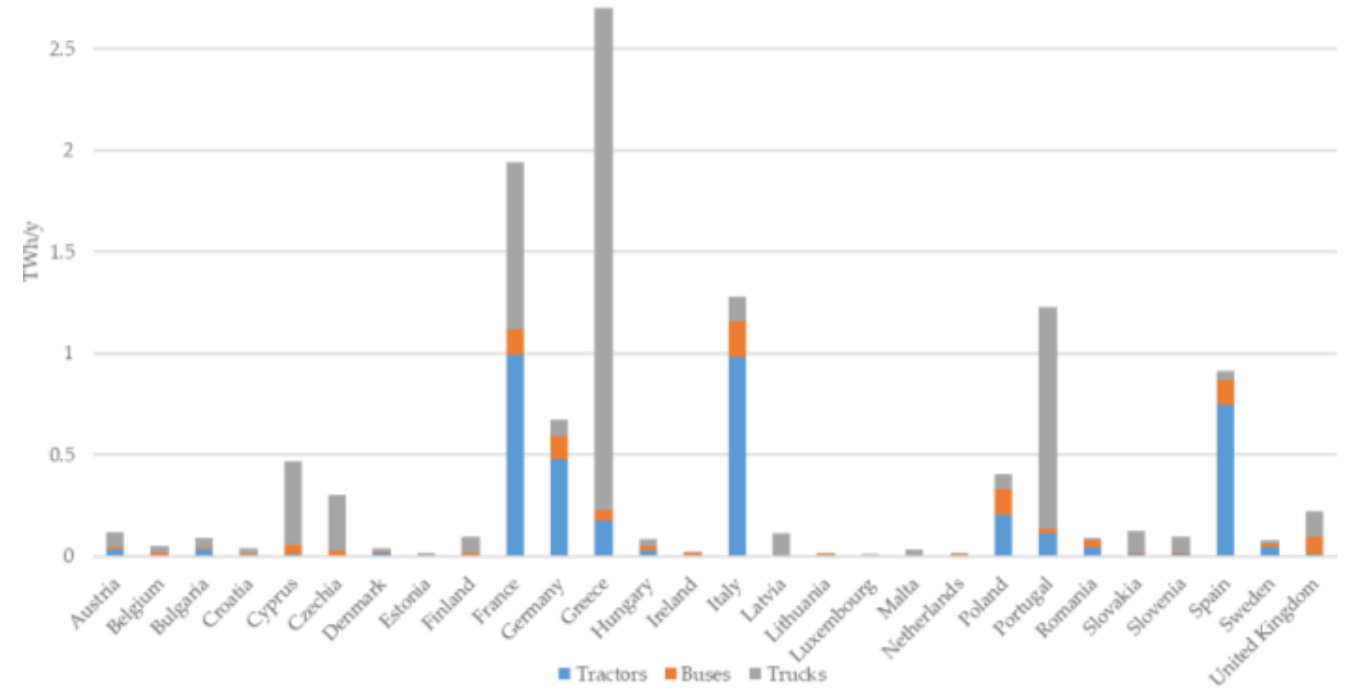

Figure 2. Final energy consumption for space cooling in the medium vehicles category for the EU27+UK-the reference year 2019.

By considering the obtained results, the most energy consuming vehicle sub-category for the whole EU27+UK is the trucks segment with more than $6 \mathrm{TWh} / \mathrm{y}$, followed by the tractors, characterized with almost $4 \mathrm{TWh} / \mathrm{y}$, and, lastly, the buses segment with more than $1 \mathrm{TWh} / \mathrm{y}$.

Concerning the buses segment, the most energy-consuming MS was found to be Italy with almost $0.18 \mathrm{TWh} / \mathrm{y}$, followed by Poland, France, Spain, and Germany with around $0.12 \mathrm{TWh} / \mathrm{y}$ each. The remaining MSs only show minor values. With regard to the tractor segment, France had the highest, with almost $1 \mathrm{TWh} / \mathrm{y}$, followed by Italy, Spain, and Germany with $0.98,0.75$, and $0.48 \mathrm{TWh} / \mathrm{y}$, respectively, while the remaining 
states present minor values. Lastly, regarding the truck segment, the greatest energyconsuming MS resulted to be Greece with almost $2.5 \mathrm{TWh} / \mathrm{y}$, followed by Portugal with more than $1 \mathrm{TWh} / \mathrm{y}$, and France with $0.8 \mathrm{TWh} / \mathrm{y}$. Lesser values are shown by the rest of the EU27+UK MSs.

The highest number of buses and trucks throughout the whole EU27+UK is held by Poland, followed by Italy, France, Germany, and Spain which similarly reflects the aforementioned FEC results [22]. Furthermore, the highest number of tractors are to find in France, Germany, Italy, Poland, and Spain. As already mentioned, the EFLHs, are connected to the CDDs and therefore different climate conditions of the EU27+UK MSs influenced the results. Still, the most influential variable of Equation (2) remains to be $\mathrm{Nr}_{\text {vehicles }}$. More details are presented in Tables A3-A5 in the Appendix A.

\subsection{Heavy Vehicles}

Concerning the heavy vehicles category, the following three main segments are involved: trains, ships, and aircrafts. Figure 3 below presents the main outcomes of the FEC for space cooling in the heavy vehicle category.

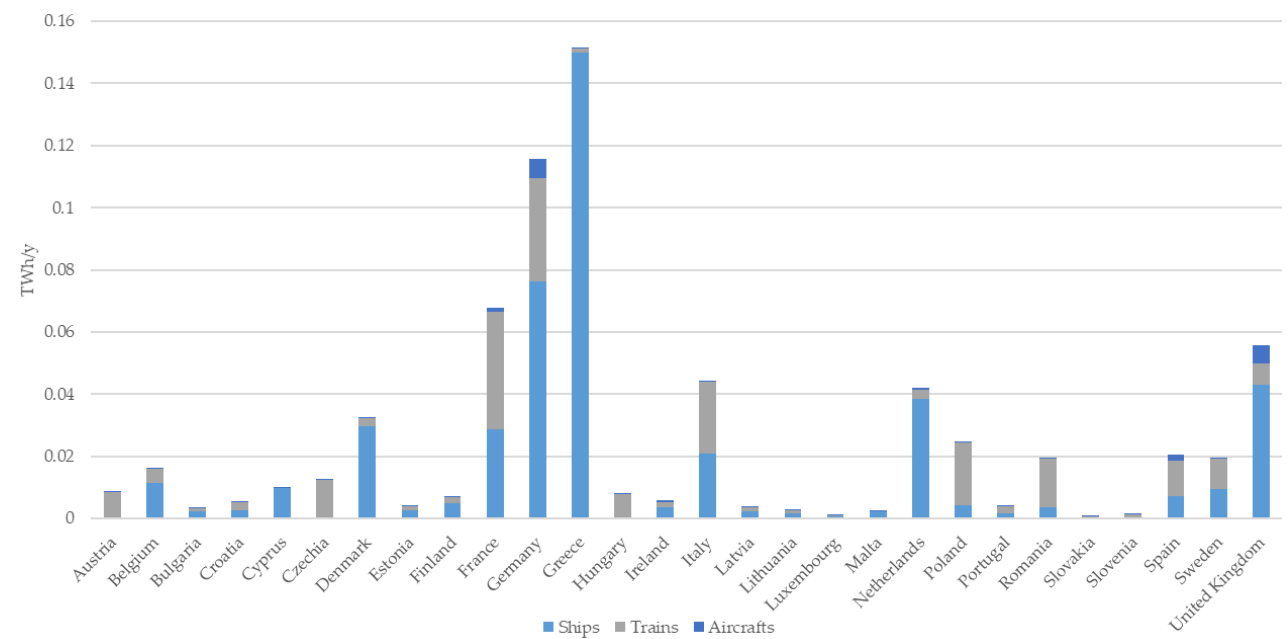

Figure 3. Final energy consumption for space cooling in the heavy vehicles category for the EU27+UK—-the reference year 2019.

It can be observed that the most energy-consuming vehicle sub-category for the whole EU27+UK was the ships segment with almost $0.5 \mathrm{TWh} / \mathrm{y}$, followed by the train and the aircraft segments with more than $0.2 \mathrm{TWh} / \mathrm{y}$ and almost $0.2 \mathrm{TWh} / \mathrm{y}$, respectively.

Greece results to be the FEC top-consumer throughout the whole EU27+UK for the ships sub-category with almost $1.5 \mathrm{TWh} / \mathrm{y}$, followed by Germany, United Kingdom, Netherlands, with $0.8,0.5$, and $0.4 \mathrm{TWh} / \mathrm{y}$, respectively, while the remaining MSs presented minor values. Moreover, regarding the trains segment, France came first with almost $0.04 \mathrm{TWh} / \mathrm{y}$, followed by Germany, Italy, and Poland with almost 0.04, 0.03, and $0.02 \mathrm{TWh} / \mathrm{y}$, respectively, and just minor results for the remaining EU27+UK MSs. Lastly, concerning the aircraft sub-category, major values are identified by Germany and United Kingdom (UK) both with $0.006 \mathrm{TWh} / \mathrm{y}$ each, while Spain comes with $0.002 \mathrm{TWh} / \mathrm{y}$, and France with more than $0.001 \mathrm{TWh} / \mathrm{y}$. The remaining EU27+UK MSs had minor values.

Notably, regarding the ship segment, as mentioned in Section 2, the most relevant source was Lugo-Villaba et al., 2017, which provided results such as the energy consumption of a vessel AHU running for space cooling [53]. In this case, regarding the EFLHs computation, most of the data sourced through the Meteonorm software were gathered from on-shore stations [39]. Therefore, in this case, the FEC weighting procedure was conducted by averaging the FEC provided by the outcomes of Lugo-Villaba et al., 2017 for the whole EU27+UK and by multiplying the result by each MS's number of vessels 
to obtain the aforementioned results. Further information is available in Tables A6-A8 in the Appendix A.

\subsection{Final Energy Consumption for Space Cooling in the European Transportation Sector}

Lastly, the results for the FEC for space cooling in the whole EU27+UK transportation sector are presented. Figure 4 below differentiates the outcomes per vehicle category.

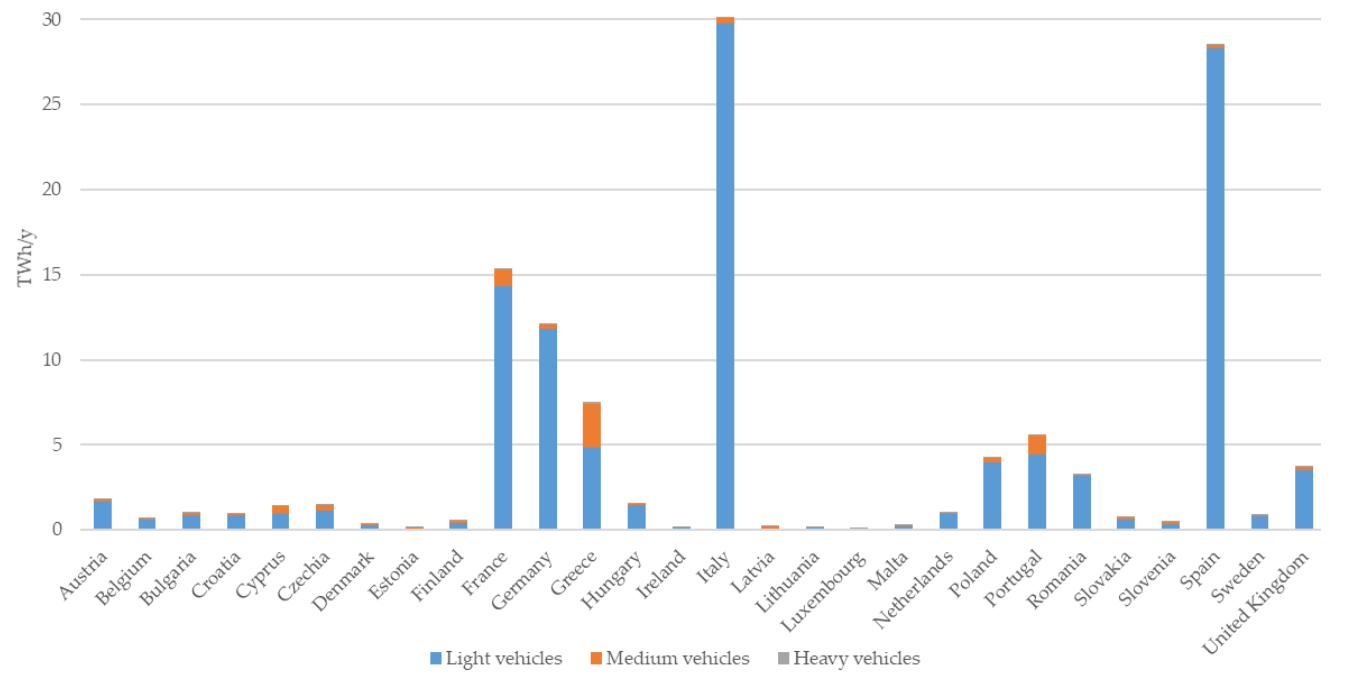

Figure 4. Final energy consumption for space cooling in the EU27+UK per vehicles category-the reference year 2019 .

By inspecting the figure, it can be said that the total FEC for space cooling results in the whole EU27+UK transportation sector to be almost $125 \mathrm{TWh} / \mathrm{y}$.

Moreover, by breaking down the different vehicle categories, the light vehicles section was found to be the most energy-consuming, with more than $115 \mathrm{TWh} / \mathrm{y}$ for the whole EU27+UK. Italy had the highest value at almost $30 \mathrm{TWh} / \mathrm{y}$, immediately followed by Spain with more than $28 \mathrm{TWh} / \mathrm{y}$ and by France and Germany with around 14 and $13 \mathrm{TWh} / \mathrm{y}$, respectively.

Concerning the medium vehicles category, the FEC for space cooling in the EU27+UK was more than $8 \mathrm{TWh} / \mathrm{y}$. Greece was found to be the most energy-consuming MS with about 2.5 TWh/y, followed by Portugal and France around $1 \mathrm{TWh} / \mathrm{y}$ each. The remaining MSs showed minor values.

Ultimately, regarding the heavy vehicles category, the FEC for space cooling of the entire EU27+UK was nearly $1 \mathrm{TWh} / \mathrm{y}$. Greece, Germany, France, the United Kingdom, and Italy were found to be the most energy-consuming, with values of $0.15,0.1,0.07,0.06$, and 0.0.4 TWh/y, respectively. Concerning the remaining MSs, lesser values are presented.

As can be observed from the information presented in Section 2 concerning the vehicle space cooling system power peak capacity, high values are reported in categories such as aircrafts, ships, and trains, which can even surpass $300 \mathrm{~kW}$, while the light and medium category is mainly dominated by values in the range of 3 to $10 \mathrm{~kW}$. According to the results presented in Figure 4, it can be clearly stated that the greatest influence in Equation (2) is given by the number of vehicles $\left(N r_{\text {vehicles }}\right)$ in all the vehicle categories. Although heavy vehicles are mainly characterized by higher space cooling system power peak capacities, they little contributed to the overall EU27+UK FEC compared to the light vehicle sector which dominates in terms of the number of vehicles.

\section{Discussion}

According to the main findings of the current study, in 2019, the FEC for space cooling (SC) in the transportation sector for the whole EU27+UK accounted for almost $125 \mathrm{TWh} / \mathrm{y}$. 
Although the topic of SC in vehicles is almost unexplored in scientific literature, Farrington et al., 2000 published by NREL considered a bottom-up approach to determine the amount of fuel used in the United States of America (U.S.) for light vehicles AC by involving the occupant thermal comfort. The assessment estimated around 27 billion liters of gasoline [27]. The aforementioned study has been essential for the current work on which approach could have been considered at the beginning of the research. Eventually, although the current study embraced a top-down approach by collecting, analysing, and processing big data at the EU27+UK, Farrington et al., 2000 has been cited as a reference for which type of information was required at the beginning of the research. Although no relevant information at the EU27+UK level has been retrieved from the above-mentioned studies, their findings contribute to the future research perspectives presented in Section 5.

Nevertheless, the results of Report 1 of the Renewable Cooling under the "Revised Renewable Energy Directive ENER/C1/2018-493" have been considered as the most relevant for the present study comparison, since similar time-reference, as well as units of measurements, are applied in both studies [60]. Particularly, the outputs of FEC for cooling of the latter, which involved SC in buildings of the residential and the service sectors, resulted to be slightly more than $105 \mathrm{TWh} / \mathrm{y}$ for the entire EU27+UK.

Overall, the FEC for SC in the transportation sector (almost $125 \mathrm{TWh} / \mathrm{y}$ ) accounts for more of the FEC for SC in the buildings sector (more than $105 \mathrm{TWh} / \mathrm{y}$ ) in the EU27+UK.

According to the results presented in Section 3, the greatest energy-consuming segment has been identified as the light vehicles section with more than $115 \mathrm{TWh} / \mathrm{y}$, followed by the medium vehicles section with more than $8 \mathrm{TWh} / \mathrm{y}$, and, finally, by the heavy vehicles section with around $1 \mathrm{TWh} / \mathrm{y}$.

The light vehicles segment is the largest portion of the transportation sector of the entire EU27+UK in terms of numbers of vehicles. Moreover, the cars sub-section was identified as being more energy-consuming than the light commercial section since the number of vehicles is significantly higher, although both the peak capacity of the SC generators and the EFLHs is equal for both sub-sections. It has been observed that, in Equation (2), the number of vehicles ( $\left.N r_{\text {vehicles }}\right)$ parameter proportionally influenced the most FEC results, followed by the EFLHs member. The latter was directly influenced by meteorological parameters of a certain MS. In the case of Poland, although the latter was characterized by a high number of vehicles in MSs such as Italy, France, Germany, and Spain, its EFLHs resulted in lower values compared to the aforementioned MSs by eventually resulting in FEC minor values.

With regard to the medium vehicles section, trucks comprise the largest number of vehicles, followed by tractors and buses. Therefore, although the peak capacity of the Rooftop AC systems applied in the trucks sub-section is significantly less compared with buses or tractors, trucks are responsible for the greatest energy consumption since it has the largest number of vehicles. As mentioned above, the number of vehicles greatly influence the current sector FEC. In this case, although France retained the highest number of trucks in the whole EU27+UK, Greece resulted to be the most energy-consuming for space cooling, since its EFLHs resulted to be higher compared to France.

Regarding the heavy vehicles element, ships, although not having the largest number in terms of vehicles, presented the highest SC peak capacity compared to the trains and aircraft systems. It is important to underline that significant data retrieving issues have been encountered in the vessels category. As previously mentioned, meteorological data obtained by the scouted datasets (please see-Section 2), were collected by on-shore stations, and therefore assumptions and simplifications have been made to retrieve FEC for the ship segment (please see-Section 3.3). Moreover, as already mentioned, the aircraft segment FEC computation method was differentiated from the other parts because the "SC" of the cabin has been assumed to occur only in a specific period - which was the "preparation-tofly" time expended in the airports (please see-Section 2). Therefore, the results came to be significantly smaller compared to the other segments mainly due to the small time spent 
on the ground by the aircraft. Further data and details, which are related to the discussion, can be found in the Appendix A.

Regarding the FEC shares, the most energy-consuming MSs across the whole EU27+UK are Italy and Spain, accounting for 24 and $23 \%$ of the whole EU27+UK FEC, respectively. France follows with $12 \%$ and Germany with 10\%. Moreover, Greece accounts for 6\%, Portugal for 4\%, and Poland, the United Kingdom, and Romania for 3\%, respectively. The remaining EU27+UK MSs had minor values of close to or of less than $1 \%$. The outcomes are influenced by different parameters, of which the greatest combination was the EFLHs and the number of vehicles that eventually led Italy and Spain to become the most energyconsuming MSs throughout the whole EU27+UK. Although Germany resulted to have the largest number of vehicles in the light segment (most cars), Cyprus presented the highest ELHSs number of the entire EU27+UK (mainly due to its warm Mediterranean climate) despite it having a significantly lower number of vehicles compared to other MSs.

Once again, it is important to underline that the current study aims to be the first research on the assessment of the final energy consumption of space cooling for human comfort in the transportation sector of the EU27+UK market. The SC sector is not heavily investigated in scientific literature, and even less so for SC in the transportation sector.

Significant data and information difficulties during the collection phase were met during the literature review phase. In addition, significant retrieving data and information tribulations have been experienced concerning lacks and gaps in the scouted databases. Notably, regarding the wheeled vehicles (cars, light commercials, tractors, trucks, and buses) market, information accessibility issues were faced, mainly related to non-disclosure policies adopted by private companies which operate in the sector. Nonetheless, research and development (R\&D) activities should be better supported by the operational sector [38].

\section{Conclusions}

The present work assessed the final energy consumption of space cooling for human comfort in the European transportation sector with 2019 as the baseline. Overall, the final energy consumption findings details of the work are summarized as follows:

- The total final energy consumption for space cooling in the European transportation sector in 2019 resulted to be more than $125 \mathrm{TWh} / \mathrm{y}$. Italy was found to be the most energy-consuming member state with $30 \mathrm{TWh} / \mathrm{y}$, followed by Spain with more than $28 \mathrm{TWh} / \mathrm{y}$, then by France with more than $15 \mathrm{TWh} / \mathrm{y}$, and Germany with $13 \mathrm{TWh} / \mathrm{y}$. These countries account for $80 \%$ of the total final energy consumption of the whole European zone. The remaining $20 \%$ is accounted for by the remaining countries. The whole transportation sector was classified into the following three main categories: light, medium, and heavy vehicles.

- The light vehicle category was divided into cars and light commercials. The total final energy consumption for space cooling in the European light vehicle segment accounted for around $116 \mathrm{TWh} / \mathrm{y}$. Italy came out to be the most energy-consuming member state with almost $30 \mathrm{TWh} / \mathrm{y}$, followed by Spain with almost $28 \mathrm{TWh} / \mathrm{y}$, then by France with 14 TWh/y, and Germany with almost $12 \mathrm{TWh} / \mathrm{y}$. These countries account for $82 \%$ of the total final energy consumption of the whole European zone. The remaining 18\% was accounted for by the rest of the European countries.

- The medium vehicle category was categorised into buses, tractors, and trucks. The total final energy consumption for space cooling in the European medium vehicle category accounted for about $11 \mathrm{TWh} / \mathrm{y}$. Greece resulted to be the greatest energyconsuming member state with about $2.7 \mathrm{TWh} / \mathrm{y}$, followed by France with almost $2 \mathrm{TWh} / \mathrm{y}$, followed by Italy with almost $1.3 \mathrm{TWh} / \mathrm{y}$, and Portugal with more than 1.2 TWh/y. These four countries account for more than $60 \%$ of the total final energy consumption of the whole European zone. The remaining $40 \%$ is accounted for by the rest of the European member states.

- The heavy vehicle category was classified into trains, ships, and aircrafts. The total final energy consumption for space cooling in the European heavy vehicle category resulted 
to be almost $0.7 \mathrm{TWh} / \mathrm{y}$. Greece presented the highest values with around 1.5 TWh/y, followed by Germany with around $0.11 \mathrm{TWh} / \mathrm{y}$, then followed by France with almost 0.07 TWh/y, then the United Kingdom with almost $0.06 \mathrm{TWh} / \mathrm{y}$, followed by Italy and Netherlands with $0.04 \mathrm{TWh} / \mathrm{y}$, respectively. Taken together, these five countries account for $70 \%$ of the entire European final energy consumption in the heavy vehicles segment. Therefore, the remaining 30\% entails the rest of the European member states.

Overall, the main finding of the present study has been that the European final space cooling consumption in the transportation sector accounted for more than the final space cooling consumption in the buildings sector, including both the residential and service portions. Given this work, it can be considered as a point of discussion for further research on the topic. Nowadays, great attention by the scientific literature is mainly focused on space heating in buildings regarding energy efficiency, savings, and developing new technologies.

Moreover, it has been observed that the light vehicles category is the largest part of the total final energy consumption of the European transportation sector. Notably, the cars segment is the most energy-demanding and the largest in terms of the number of operating transports (which is principally driven by private companies). Given the fact that, currently, great attention is given to the electric automotive sector, potential further research could be focused on the space cooling energy consumption for human comfort in the electric vehicles which could lead to different results compared to this study due to the different space cooling system capacities.

During the literature review, which involved the scouting of numerous sources, the authors faced relevant data and information-collection issues since knowledge from certain European member states, as well as from certain vehicles categories and cooling technologies, are inconsistent, fragmented, unavailable, or even outdated. Therefore, better accessibility, as well as reliability of data and information and major involvement of the private sector, is necessary for research and development purposes.

According to what has been stated above, it can be said that the current study is the first outlook and a potential reference on a highly unexplored field in the European scientific literature.

In conclusion, space cooling in the transportation sector is expected to grow in the future according to different drivers such as climate change, which increases space cooling demand, driven by soaring temperatures and humidity during summers, as well as the increase in the number of vehicles due to the expected growth in population and welfare throughout the member states of the European Union.

Author Contributions: Conceptualization, G.Q. and S.P.; Data curation G.Q. and A.G.; Writing, G.Q.; Supervision, S.P.; Validation, S.P. and E.W. All authors have read and agreed to the published version of the manuscript.

Funding: This research received no external funding.

Institutional Review Board Statement: Not applicable.

Informed Consent Statement: Not applicable.

Conflicts of Interest: The authors declare no conflict of interest. 


\section{Appendix A}

Table A1. Light vehicles segment-Final space cooling energy consumption of cars in the EU27+UK, the reference year 2019

\begin{tabular}{|c|c|c|c|c|c|c|}
\hline Country & $\mathbf{n}^{\circ}$ of Cars & $\begin{array}{l}\text { Cooling System } \\
\text { Capacity }[\mathrm{kW}]\end{array}$ & EFLHs [h] & $\begin{array}{l}\text { Energy } \\
\text { Efficiency }\end{array}$ & $\begin{array}{l}\text { Work Input } \\
{[\mathrm{kW}]}\end{array}$ & FEC [TWh] \\
\hline Austria & $4,978,852$ & 3 & 368 & 3.42 & 0.877192982 & 1.40726815 \\
\hline Belgium & $5,782,685$ & 3 & 276 & 3.57 & 0.840336134 & 0.448605678 \\
\hline Bulgaria & 2829964 & 3 & 276 & 3.51 & 0.854700855 & 0.625701722 \\
\hline Croatia & $1,665,391$ & 3 & 552 & 3.66 & 0.819672131 & 0.722723942 \\
\hline Cyprus & 572,501 & 3 & 552 & 3.4 & 0.882352941 & 0.614926321 \\
\hline Czechia & $5,802,520$ & 3 & 276 & 3.25 & 0.923076923 & 0.950594355 \\
\hline Denmark & $2,593,568$ & 3 & 184 & 4.02 & 0.746268657 & 0.199331375 \\
\hline Estonia & 746,464 & 3 & 184 & 4.04 & 0.742574257 & 0.078514739 \\
\hline Finland & $2,696,334$ & 3 & 184 & 3.25 & 0.923076923 & 0.310101985 \\
\hline France & $33,020,132$ & 3 & 460 & 3.38 & 0.887573964 & 10.20529244 \\
\hline Germany & $47,095,784$ & 3 & 460 & 3.32 & 0.903614458 & 10.52729641 \\
\hline Greece & $5,164,183$ & 3 & 552 & 3.29 & 0.911854103 & 3.527751136 \\
\hline Hungary & $3,638,374$ & 3 & 276 & 3.28 & 0.914634146 & 1.146928637 \\
\hline Ireland & $2,104,060$ & 3 & 184 & 3.66 & 0.819672131 & 0.081260881 \\
\hline Italy & $39,018,170$ & 3 & 552 & 3.23 & 0.928792571 & 24.2693347 \\
\hline Latvia & 636,671 & 3 & 184 & 4.04 & 0.742574257 & 0.031482682 \\
\hline Lithuania & $1,430,520$ & 3 & 184 & 4.06 & 0.738916256 & 0.114531905 \\
\hline Luxembourg & 415,128 & 3 & 184 & 3.75 & 0.816298091 & 0.034924181 \\
\hline Malta & 307,130 & 3 & 552 & 3.4 & 0.882352941 & 0.227737384 \\
\hline Netherlands & $8,787,283$ & 3 & 184 & 3.37 & 0.890207715 & 0.763538686 \\
\hline Poland & $23,429,016$ & 3 & 184 & 3.45 & 0.869565217 & 3.207479231 \\
\hline Portugal & $5,015,057$ & 3 & 552 & 3.21 & 0.934579439 & 2.985544189 \\
\hline Romania & $6,450,750$ & 3 & 276 & 3.35 & 0.895522388 & 2.543396091 \\
\hline Slovakia & $2,326,787$ & 3 & 368 & 3.86 & 0.777202073 & 0.484176646 \\
\hline Slovenia & $1,203,774$ & 3 & 368 & 3.66 & 0.819672131 & 0.29091479 \\
\hline Spain & $24,074,216$ & 3 & 552 & 3.21 & 0.934579439 & 20.04833209 \\
\hline Sweden & $4,870,783$ & 3 & 184 & 3.41 & 0.879765396 & 0.629297496 \\
\hline United Kingdom & $34,887,915$ & 3 & 368 & 3.39 & 0.884955752 & 2.736965813 \\
\hline
\end{tabular}

Table A2. Light vehicles segment-Final space cooling energy consumption of light commercials in the EU27+UK, the reference year 2019.

\begin{tabular}{|c|c|c|c|c|c|c|}
\hline Country & $\begin{array}{l}\mathbf{n}^{\circ} \text { of Light- } \\
\text { Commercials }\end{array}$ & $\begin{array}{c}\text { Cooling System } \\
\text { Capacity }[\mathrm{kW}]\end{array}$ & EFLHs [h] & $\begin{array}{l}\text { Energy } \\
\text { Efficiency }\end{array}$ & $\begin{array}{c}\text { Work Input } \\
{[\mathrm{kW}]}\end{array}$ & FEC [TWh] \\
\hline Austria & 422,745 & 6.4 & 322.22 & 3.42 & 1.871345029 & 0.254908807 \\
\hline Belgium & 769,386 & 6.4 & 92.31710824 & 3.57 & 1.792717087 & 0.127332196 \\
\hline Bulgaria & 558,037 & 6.4 & 258.6856283 & 3.51 & 1.823361823 & 0.263213496 \\
\hline Croatia & 135,800 & 6.4 & 529.4391585 & 3.66 & 1.74863388 & 0.125722995 \\
\hline Cyprus & 130,941 & 6.4 & 1217.319266 & 3.4 & 1.882352941 & 0.300041416 \\
\hline Czechia & 574,722 & 6.4 & 177.4764328 & 3.25 & 1.969230769 & 0.200860771 \\
\hline Denmark & 389,350 & 6.4 & 102.9870981 & 4.02 & 1.592039801 & 0.063837654 \\
\hline Estonia & 83,307 & 6.4 & 141.6453873 & 4.04 & 1.584158416 & 0.018693152 \\
\hline Finland & 325,656 & 6.4 & 124.5928052 & 3.25 & 1.969230769 & 0.079900346 \\
\hline France & $6,233,473$ & 6.4 & 348.2106861 & 3.38 & 1.893491124 & 4.109939712 \\
\hline Germany & $2,724,783$ & 6.4 & 247.3726315 & 3.32 & 1.927710843 & 1.299347935 \\
\hline Greece & 889,638 & 6.4 & 749.1537536 & 3.29 & 1.945288754 & 1.296487581 \\
\hline Hungary & 446,647 & 6.4 & 344.6526691 & 3.28 & 1.951219512 & 0.300366987 \\
\hline Ireland & 380,883 & 6.4 & 47.11760842 & 3.66 & 1.74863388 & 0.031381501 \\
\hline Italy & $4,146,206$ & 6.4 & 669.6875761 & 3.23 & 1.981424149 & 5.50174642 \\
\hline Latvia & 50,835 & 6.4 & 66.59118884 & 4.04 & 1.584158416 & 0.005362635 \\
\hline Lithuania & 49,576 & 6.4 & 108.3520986 & 4.06 & 1.57635468 & 0.008467647 \\
\hline
\end{tabular}


Table A2. Cont.

\begin{tabular}{ccccccc}
\hline Country & $\begin{array}{c}\mathbf{n}^{\circ} \text { of Light- } \\
\text { Commercials }\end{array}$ & $\begin{array}{c}\text { Cooling System } \\
\text { Capacity [kW] }\end{array}$ & EFLHs [h] & $\begin{array}{c}\text { Energy } \\
\text { Efficiency }\end{array}$ & $\begin{array}{c}\text { Work Input } \\
{[\mathbf{k W}]}\end{array}$ & FEC [TWh] \\
\hline Luxembourg & 36,603 & 6.4 & 105.1608813 & 3.75 & 1.706666667 & 0.006569308 \\
Malta & 4472 & 6.4 & 840.3684724 & 3.4 & 1.882352941 & 0.007074123 \\
Netherlands & 995,796 & 6.4 & 97.60792473 & 3.37 & 1.899109792 & 0.184588878 \\
Poland & $2,649,198$ & 6.4 & 157.4373041 & 3.45 & 1.855072464 & 0.77371843 \\
Portugal & $1,120,270$ & 6.4 & 636.9882301 & 3.21 & 1.99376947 & 1.422751511 \\
Romania & 758,037 & 6.4 & 440.2783607 & 3.35 & 1.910447761 & 0.637606759 \\
Slovakia & 259,629 & 6.4 & 267.74 & 3.86 & 1.658031088 & 0.115254829 \\
Slovenia & 105,360 & 6.4 & 294.8361107 & 3.66 & 1.74863388 & 0.054319445 \\
Spain & $4,640,154$ & 6.4 & 891.0659992 & 3.21 & 1.99376947 & 8.243605653 \\
Sweden & 572,075 & 6.4 & 146.855544 & 3.41 & 1.876832845 & 0.157677204 \\
United Kingdom & $4,407,561$ & 6.4 & 88.64878766 & 3.39 & 1.887905605 & 0.737651803 \\
\hline
\end{tabular}

Table A3. Medium vehicles segment-Final space cooling energy consumption of buses in the EU27+UK, the reference year 2019.

\begin{tabular}{|c|c|c|c|c|c|c|c|}
\hline Country & $n^{\circ}$ of Buses & $\begin{array}{c}\text { Rooftop AC } \\
\text { System Capacity } \\
{[\mathrm{kW}]}\end{array}$ & $\begin{array}{c}\text { Integrated AC } \\
\text { System Capacity } \\
{[\mathrm{kW}]}\end{array}$ & EFLHs [h] & $\begin{array}{c}\text { Energy } \\
\text { Efficiency }\end{array}$ & $\begin{array}{c}\text { Work Input } \\
{[\mathrm{kW}]}\end{array}$ & FEC [TWh] \\
\hline Austria & 10,148 & $3.5-8.5$ & $4-9.6$ & 617.4051352 & 3.42 & 1.871345029 & 0.011724776 \\
\hline Belgium & 16,486 & $3.5-8.5$ & $4-9.6$ & 525.6602203 & 3.57 & 1.792717087 & 0.015535748 \\
\hline Bulgaria & 20,687 & $3.5-8.5$ & $4-9.6$ & 258.6856283 & 3.51 & 1.823361823 & 0.009757592 \\
\hline Croatia & 5141 & $3.5-8.5$ & $4-9.6$ & 796.1426387 & 3.66 & 1.74863388 & 0.007157105 \\
\hline Cyprus & 22,337 & $3.5-8.5$ & $4-9.6$ & 1045.413774 & 3.4 & 1.882352941 & 0.043955591 \\
\hline Czechia & 21,443 & $3.5-8.5$ & $4-9.6$ & 543.2958441 & 3.25 & 1.969230769 & 0.022941327 \\
\hline Denmark & 8982 & $3.5-8.5$ & $4-9.6$ & 490.5720542 & 4.02 & 1.592039801 & 0.007015034 \\
\hline Estonia & 4973 & $3.5-8.5$ & $4-9.6$ & 489.4154688 & 4.04 & 1.584158416 & 0.003855625 \\
\hline Finland & 12,481 & $3.5-8.5$ & $4-9.6$ & 524.9178456 & 3.25 & 1.969230769 & 0.012901415 \\
\hline France & 92,498 & $3.5-8.5$ & $4-9.6$ & 709.7051699 & 3.38 & 1.893491124 & 0.124300703 \\
\hline Germany & 106,024 & $3.5-8.5$ & $4-9.6$ & 555.7838302 & 3.32 & 1.927710843 & 0.113593108 \\
\hline Greece & 27,970 & $3.5-8.5$ & $4-9.6$ & 940.184941 & 3.29 & 1.945288754 & 0.051155205 \\
\hline Hungary & 19,454 & $3.5-8.5$ & $4-9.6$ & 667.4978107 & 3.28 & 1.951219512 & 0.025337566 \\
\hline Ireland & 10,944 & $3.5-8.5$ & $4-9.6$ & 477.0265284 & 3.66 & 1.74863388 & 0.00912888 \\
\hline Italy & 100,042 & $3.5-8.5$ & $4-9.6$ & 889.8351614 & 3.23 & 1.981424149 & 0.17638814 \\
\hline Latvia & 4035 & $3.5-8.5$ & $4-9.6$ & 516.6464251 & 4.04 & 1.584158416 & 0.003302445 \\
\hline Lithuania & 7517 & $3.5-8.5$ & $4-9.6$ & 505.4210506 & 4.06 & 1.57635468 & 0.005988966 \\
\hline Luxembourg & 1963 & $3.5-8.5$ & $4-9.6$ & 543.6704544 & 3.75 & 1.706666667 & 0.001821398 \\
\hline Malta & 876 & $3.5-8.5$ & $4-9.6$ & 973.2379443 & 3.4 & 1.882352941 & 0.001604812 \\
\hline Netherlands & 10,055 & $3.5-8.5$ & $4-9.6$ & 524.0419209 & 3.37 & 1.899109792 & 0.010006868 \\
\hline Poland & 119,471 & $3.5-8.5$ & $4-9.6$ & 561.5596548 & 3.45 & 1.855072464 & 0.124456985 \\
\hline Portugal & 16,200 & $3.5-8.5$ & $4-9.6$ & 741.2477614 & 3.21 & 1.99376947 & 0.02394161 \\
\hline Romania & 23,935 & $3.5-8.5$ & $4-9.6$ & 741.2920198 & 3.35 & 1.910447761 & 0.033896739 \\
\hline Slovakia & 9078 & $3.5-8.5$ & $4-9.6$ & 651.4207554 & 3.86 & 1.658031088 & 0.009804929 \\
\hline Slovenia & 2850 & $3.5-8.5$ & $4-9.6$ & 616.7809655 & 3.66 & 1.74863388 & 0.003073794 \\
\hline Spain & 64,915 & $3.5-8.5$ & $4-9.6$ & 923.533643 & 3.21 & 1.99376947 & 0.119528845 \\
\hline Sweden & 14,378 & $3.5-8.5$ & $4-9.6$ & 510.9332798 & 3.41 & 1.876832845 & 0.013787587 \\
\hline United Kingdom & 84,391 & $3.5-8.5$ & $4-9.6$ & 533.8931404 & 3.39 & 1.887905605 & 0.085061052 \\
\hline
\end{tabular}

Table A4. Medium vehicles segment-Final space cooling energy consumption of trucks in the EU27+UK, the reference year 2019 .

\begin{tabular}{|c|c|c|c|c|c|c|}
\hline Country & $\mathbf{n}^{\circ}$ of Trucks & $\begin{array}{l}\text { Cooling System } \\
\text { Capacity }[\mathrm{kW}]\end{array}$ & EFLHs [h] & $\begin{array}{c}\text { Energy } \\
\text { Efficiency }\end{array}$ & $\begin{array}{c}\text { Work Input } \\
{[\mathrm{kW}]}\end{array}$ & FEC [TWh] \\
\hline Austria & 494,585 & 1.6 & 617.4051352 & 3.42 & 0.467836257 & 0.074556809 \\
\hline Belgium & 885,487 & 1.6 & 525.6602203 & 3.57 & 0.448179272 & 0.036636683 \\
\hline Bulgaria & 401,823 & 1.6 & 258.6856283 & 3.51 & 0.455840456 & 0.047382717 \\
\hline Croatia & 112,468 & 1.6 & 796.1426387 & 3.66 & 0.43715847 & 0.026030585 \\
\hline Cyprus & 719,687 & 1.6 & 1045.413774 & 3.4 & 0.470588235 & 0.412277106 \\
\hline Czechia & $3,149,263$ & 1.6 & 543.2958441 & 3.25 & 0.492307692 & 0.275160597 \\
\hline Denmark & 408,094 & 1.6 & 490.5720542 & 4.02 & 0.39800995 & 0.016727728 \\
\hline
\end{tabular}


Table A4. Cont.

\begin{tabular}{|c|c|c|c|c|c|c|}
\hline Country & $n^{\circ}$ of Trucks & $\begin{array}{c}\text { Cooling System } \\
\text { Capacity }[\mathrm{kW}]\end{array}$ & EFLHs [h] & $\begin{array}{l}\text { Energy } \\
\text { Efficiency }\end{array}$ & $\begin{array}{c}\text { Work Input } \\
{[\mathrm{kW}]}\end{array}$ & FEC [TWh] \\
\hline Estonia & 118,125 & 1.6 & 489.4154688 & 4.04 & 0.396039604 & 0.00662648 \\
\hline Finland & $1,304,839$ & 1.6 & 524.9178456 & 3.25 & 0.492307692 & 0.08003621 \\
\hline France & $5,015,973$ & 1.6 & 709.7051699 & 3.38 & 0.473372781 & 0.826800189 \\
\hline Germany & 646,483 & 1.6 & 555.7838302 & 3.32 & 0.481927711 & 0.07707094 \\
\hline Greece & $6,784,661$ & 1.6 & 940.184941 & 3.29 & 0.486322188 & 2.471856173 \\
\hline Hungary & 180,674 & 1.6 & 667.4978107 & 3.28 & 0.487804878 & 0.030375501 \\
\hline Ireland & 519,231 & 1.6 & 477.0265284 & 3.66 & 0.43715847 & 0.010695048 \\
\hline Italy & 351,588 & 1.6 & 889.8351614 & 3.23 & 0.495356037 & 0.116633618 \\
\hline Latvia & $4,175,689$ & 1.6 & 516.6464251 & 4.04 & 0.396039604 & 0.110124394 \\
\hline Lithuania & 95,464 & 1.6 & 505.4210506 & 4.06 & 0.39408867 & 0.004076345 \\
\hline Luxembourg & 42,017 & 1.6 & 543.6704544 & 3.75 & 0.426666667 & 0.001885246 \\
\hline Malta & 76,425 & 1.6 & 973.2379443 & 3.4 & 0.470588235 & 0.030223605 \\
\hline Netherlands & 49,491 & 1.6 & 524.0419209 & 3.37 & 0.474777448 & 0.002293514 \\
\hline Poland & $1,002,882$ & 1.6 & 561.5596548 & 3.45 & 0.463768116 & 0.073224829 \\
\hline Portugal & $3,436,184$ & 1.6 & 741.2477614 & 3.21 & 0.498442368 & 1.090995023 \\
\hline Romania & 60,797 & 1.6 & 741.2920198 & 3.35 & 0.47761194 & 0.012784527 \\
\hline Slovakia & 943,062 & 1.6 & 651.4207554 & 3.86 & 0.414507772 & 0.104661314 \\
\hline Slovenia & 653,879 & 1.6 & 616.7809655 & 3.66 & 0.43715847 & 0.084278532 \\
\hline Spain & 99,231 & 1.6 & 923.533643 & 3.21 & 0.498442368 & 0.044072957 \\
\hline Sweden & 296,952 & 1.6 & 510.9332798 & 3.41 & 0.469208211 & 0.020461723 \\
\hline United Kingdom & 919,231 & 1.6 & 533.8931404 & 3.39 & 0.471976401 & 0.126236426 \\
\hline
\end{tabular}

Table A5. Medium vehicles segment-Final space cooling energy consumption of tractors in the EU27+UK, the reference year 2019.

\begin{tabular}{|c|c|c|c|c|c|c|c|}
\hline Country & $\begin{array}{c}\mathbf{n}^{\circ} \text { of } \\
\text { Tractors }\end{array}$ & $\begin{array}{c}\text { Rooftop AC } \\
\text { System Capacity } \\
{[\mathrm{kW}]}\end{array}$ & $\begin{array}{c}\text { Integrated AC } \\
\text { System Capacity } \\
{[\mathrm{kW}]}\end{array}$ & EFLHs [h] & $\begin{array}{l}\text { Energy } \\
\text { Efficiency }\end{array}$ & $\begin{array}{l}\text { Work Input } \\
{[\mathrm{kW}]}\end{array}$ & FEC [TWh] \\
\hline Austria & 58,651 & $3.5-8.5$ & $4-9.6$ & 322.22 & 3.42 & 1.871345029 & 0.035365829 \\
\hline Belgium & 8970 & $3.5-8.5$ & $4-9.6$ & 92.31710824 & 3.57 & 1.792717087 & 0.001484452 \\
\hline Bulgaria & 68,698 & $3.5-8.5$ & $4-9.6$ & 258.6856283 & 3.51 & 1.823361823 & 0.032403116 \\
\hline Croatia & 4620 & $3.5-8.5$ & $4-9.6$ & 529.4391585 & 3.66 & 1.74863388 & 0.004276955 \\
\hline Cyprus & 4543 & $3.5-8.5$ & $4-9.6$ & 1217.319266 & 3.4 & 1.882352941 & 0.010409942 \\
\hline Czechia & 9842 & $3.5-8.5$ & $4-9.6$ & 177.4764328 & 3.25 & 1.969230769 & 0.003439626 \\
\hline Denmark & 102,275 & $3.5-8.5$ & $4-9.6$ & 102.9870981 & 4.02 & 1.592039801 & 0.016768885 \\
\hline Estonia & 14,762 & $3.5-8.5$ & $4-9.6$ & 141.6453873 & 4.04 & 1.584158416 & 0.003312536 \\
\hline Finland & 26,121 & $3.5-8.5$ & $4-9.6$ & 124.5928052 & 3.25 & 1.969230769 & 0.006408851 \\
\hline France & $1,506,502$ & $3.5-8.5$ & $4-9.6$ & 348.2106861 & 3.38 & 1.893491124 & 0.993287754 \\
\hline Germany & $1,007,340$ & $3.5-8.5$ & $4-9.6$ & 247.3726315 & 3.32 & 1.927710843 & 0.480363059 \\
\hline Greece & 122,837 & $3.5-8.5$ & $4-9.6$ & 749.1537536 & 3.29 & 1.945288754 & 0.179013389 \\
\hline Hungary & 40,059 & $3.5-8.5$ & $4-9.6$ & 344.6526691 & 3.28 & 1.951219512 & 0.026939089 \\
\hline Ireland & 56,782 & $3.5-8.5$ & $4-9.6$ & 47.11760842 & 3.66 & 1.74863388 & 0.004678375 \\
\hline Italy & 742,146 & $3.5-8.5$ & $4-9.6$ & 669.6875761 & 3.23 & 1.981424149 & 0.984779992 \\
\hline Latvia & 6164 & $3.5-8.5$ & $4-9.6$ & 66.59118884 & 4.04 & 1.584158416 & 0.00065028 \\
\hline Lithuania & 43,874 & $3.5-8.5$ & $4-9.6$ & 108.3520986 & 4.06 & 1.57635468 & 0.00749371 \\
\hline Luxembourg & 6186 & $3.5-8.5$ & $4-9.6$ & 105.1608813 & 3.75 & 1.7066666667 & 0.001110234 \\
\hline Malta & 383 & $3.5-8.5$ & $4-9.6$ & 840.3684724 & 3.4 & 1.882352941 & 0.000605856 \\
\hline Netherlands & 19,853 & $3.5-8.5$ & $4-9.6$ & 97.60792473 & 3.37 & 1.899109792 & 0.003680148 \\
\hline Poland & 704,918 & $3.5-8.5$ & $4-9.6$ & 157.4373041 & 3.45 & 1.855072464 & 0.205876736 \\
\hline Portugal & 89,363 & $3.5-8.5$ & $4-9.6$ & 636.9882301 & 3.21 & 1.99376947 & 0.113491093 \\
\hline Romania & 55,587 & $3.5-8.5$ & $4-9.6$ & 440.2783607 & 3.35 & 1.910447761 & 0.046755827 \\
\hline Slovakia & 18,305 & $3.5-8.5$ & $4-9.6$ & 267.74 & 3.86 & 1.658031088 & 0.008126064 \\
\hline Slovenia & 23,007 & $3.5-8.5$ & $4-9.6$ & 294.8361107 & 3.66 & 1.74863388 & 0.011861609 \\
\hline Spain & 421,714 & $3.5-8.5$ & $4-9.6$ & 891.0659992 & 3.21 & 1.99376947 & 0.749208108 \\
\hline Sweden & 167,297 & $3.5-8.5$ & $4-9.6$ & 146.855544 & 3.41 & 1.876832845 & 0.046111086 \\
\hline United Kingdom & 72,959 & $3.5-8.5$ & $4-9.6$ & 88.64878766 & 3.39 & 1.887905605 & 0.012210426 \\
\hline
\end{tabular}


Table A6. Heavy vehicles segment-Final space cooling energy consumption of aircrafts in the EU27+UK, the reference year 2019.

\begin{tabular}{|c|c|c|c|c|c|c|c|}
\hline Country & $\mathbf{n}^{\circ}$ of Aircrafts & $\begin{array}{c}n^{\circ} \text { of Yearly } \\
\text { Flights }\end{array}$ & $\begin{array}{l}\text { ACM System } \\
\text { Capacity [kW] }\end{array}$ & EFLHs [h] & $\begin{array}{l}\text { Energy } \\
\text { Efficiency }\end{array}$ & $\begin{array}{l}\text { Work Input } \\
{[\mathrm{kW}]}\end{array}$ & FEC [TWh] \\
\hline Austria & 459 & 234 & 56 & 58.5 & 4 & 15.12228261 & 0.000406056 \\
\hline Belgium & 176 & 208 & 56 & 52 & 3.84 & 14.4921875 & 0.000132633 \\
\hline Bulgaria & 61 & 52 & 56 & 13 & 3.86 & 14.41709845 & $1.14328 \times 10^{5}$ \\
\hline Croatia & 36 & 38 & 56 & 9.5 & 3.86 & 14.41709845 & $4.93065 \times 10^{6}$ \\
\hline Cyprus & 15 & 76 & 56 & 19 & 3.82 & 14.56806283 & $4.1519 \times 10^{6}$ \\
\hline Czechia & 73 & 139 & 56 & 34.75 & 3.73 & 14.91957105 & $3.78472 \times 10^{5}$ \\
\hline Denmark & 149 & 254 & 56 & 63.5 & 3.82 & 14.56806283 & 0.000137836 \\
\hline Estonia & 45 & 40 & 56 & 10 & 3.83 & 14.53002611 & $6.53851 \times 10^{6}$ \\
\hline Finland & 93 & 181 & 56 & 45.25 & 3.81 & 14.60629921 & $6.1467 \times 10^{5}$ \\
\hline France & 553 & 680 & 56 & 170 & 3.81 & 14.60629921 & 0.001373138 \\
\hline Germany & 1134 & 1405 & 56 & 351.25 & 3.61 & 15.41551247 & 0.006140268 \\
\hline Greece & 118 & 205 & 56 & 51.25 & 3.85 & 14.45454545 & $8.74139 \times 10^{5}$ \\
\hline Hungary & 120 & 102 & 56 & 25.5 & 3.7 & 15.04054054 & $4.60241 \times 10^{5}$ \\
\hline Ireland & 666 & 218 & 56 & 54.5 & 3.85 & 14.45454545 & 0.000524657 \\
\hline Italy & 274 & 486 & 56 & 121.5 & 3.7 & 15.04054054 & 0.000500715 \\
\hline Latvia & 57 & 78 & 56 & 19.5 & 3.81 & 14.60629921 & $1.62349 \times 10^{5}$ \\
\hline Lithuania & 44 & 52 & 56 & 13 & 3.81 & 14.60629921 & $8.3548 \times 10^{6}$ \\
\hline Luxembourg & 127 & 55 & 56 & 13.75 & 3.84 & 14.4921875 & $2.5307 \times 10^{5}$ \\
\hline Malta & 202 & 22 & 56 & 5.5 & 3.82 & 14.56806283 & $1.61851 \times 10^{5}$ \\
\hline Netherlands & 260 & 487 & 56 & 121.75 & 3.76 & 14.80053191 & 0.000468511 \\
\hline Poland & 160 & 172 & 56 & 43 & 3.88 & 14.34278351 & $9.86784 \times 10^{5}$ \\
\hline Portugal & 239 & 216 & 56 & 54 & 3.8 & 14.64473684 & 0.000189005 \\
\hline Romania & 63 & 114 & 56 & 28.5 & 3.82 & 14.56806283 & $2.6157 \times 10^{5}$ \\
\hline Slovakia & 19 & 29 & 56 & 7.25 & 3.84 & 14.4921875 & $1.9963 \times 10^{6}$ \\
\hline Slovenia & 38 & 25 & 56 & 6.25 & 3.85 & 14.45454545 & $3.43295 \times 10^{6}$ \\
\hline Spain & 528 & 1035 & 56 & 258.75 & 3.77 & 14.76127321 & 0.002016685 \\
\hline Sweden & 272 & 231 & 56 & 57.75 & 3.77 & 14.76127321 & 0.00023187 \\
\hline United Kingdom & 1300 & 1235 & 56 & 308.75 & 3.66 & 15.20491803 & 0.006102874 \\
\hline
\end{tabular}

Table A7. Heavy vehicles segment-Final space cooling energy consumption of trains in the EU27+UK, the reference year 2019.

\begin{tabular}{|c|c|c|c|c|c|c|}
\hline Country & $\begin{array}{l}\mathbf{n}^{\circ} \text { of Locomotives } \\
\text { and Railcars }\end{array}$ & $\begin{array}{c}\text { Rooftop Mounted } \\
\text { Units System } \\
\text { Capacity }[\mathrm{kW}]\end{array}$ & EFLHs [h] & Energy Efficiency & $\begin{array}{l}\text { Work Input } \\
{[\mathrm{kW}]}\end{array}$ & FEC [TWh] \\
\hline Austria & 1849 & $20-35$ & 617.4051352 & 3.96 & 6.944444444 & 0.007927653 \\
\hline Belgium & 1277 & $20-35$ & 525.6602203 & 3.86 & 7.124352332 & 0.004781165 \\
\hline Bulgaria & 452 & $20-35$ & 258.6856283 & 3.83 & 7.180156658 & 0.000839082 \\
\hline Croatia & 433 & $20-35$ & 796.1426387 & 3.75 & 7.333333333 & 0.002528018 \\
\hline Cyprus & 0 & $20-35$ & 1045.413774 & 0 & 0 & 0 \\
\hline Czechia & 3139 & $20-35$ & 543.2958441 & 3.82 & 7.19895288 & 0.012277135 \\
\hline Denmark & 741 & $20-35$ & 490.5720542 & 3.56 & 7.724719101 & 0.002808043 \\
\hline Estonia & 266 & $20-35$ & 489.4154688 & 3.55 & 7.746478873 & 0.001008472 \\
\hline Finland & 570 & $20-35$ & 524.9178456 & 3.83 & 7.180156658 & 0.002148326 \\
\hline France & 7566 & $20-35$ & 709.7051699 & 3.91 & 7.033248082 & 0.037765935 \\
\hline Germany & 8533 & $20-35$ & 555.7838302 & 3.92 & 7.015306122 & 0.033270967 \\
\hline Greece & 217 & $20-35$ & 940.184941 & 3.79 & 7.255936675 & 0.001480357 \\
\hline Hungary & 1706 & $20-35$ & 667.4978107 & 3.91 & 7.033248082 & 0.00800912 \\
\hline Ireland & 482 & $20-35$ & 477.0265284 & 3.83 & 7.180156658 & 0.00165091 \\
\hline Italy & 3728 & $20-35$ & 889.8351614 & 3.93 & 6.997455471 & 0.023213128 \\
\hline Latvia & 325 & $20-35$ & 516.6464251 & 3.77 & 7.294429708 & 0.001224808 \\
\hline Lithuania & 268 & $20-35$ & 505.4210506 & 3.77 & 7.294429708 & 0.000988051 \\
\hline Luxembourg & 126 & $20-35$ & 543.6704544 & 3.8 & 7.236842105 & 0.000495742 \\
\hline Malta & 0 & 20-35 & 973.2379443 & 0 & 0 & 0 \\
\hline Netherlands & 810 & 20-35 & 524.0419209 & 3.87 & 7.105943152 & 0.003016288 \\
\hline Poland & 5197 & $20-35$ & 561.5596548 & 3.96 & 6.944444444 & 0.020266844 \\
\hline Portugal & 377 & $20-35$ & 741.2477614 & 3.77 & 7.294429708 & 0.002038431 \\
\hline Romania & 2995 & $20-35$ & 741.2920198 & 3.89 & 7.06940874 & 0.015695286 \\
\hline Slovakia & 132 & $20-35$ & 651.4207554 & 3.8 & 7.236842105 & 0.000622278 \\
\hline
\end{tabular}


Table A7. Cont.

\begin{tabular}{|c|c|c|c|c|c|c|}
\hline Country & $\begin{array}{l}\mathrm{n}^{\circ} \text { of Locomotives } \\
\text { and Railcars }\end{array}$ & $\begin{array}{l}\text { Rooftop Mounted } \\
\text { Units System } \\
\text { Capacity [kW] }\end{array}$ & EFLHs [h] & Energy Efficiency & $\begin{array}{l}\text { Work Input } \\
{[\mathrm{kW}]}\end{array}$ & FEC [TWh] \\
\hline Slovenia & 252 & $20-35$ & 616.7809655 & 3.82 & 7.19895288 & 0.001118925 \\
\hline Spain & 1716 & $20-35$ & 923.533643 & 3.78 & 7.275132275 & 0.011529511 \\
\hline Sweden & 2771 & $20-35$ & 510.9332798 & 3.97 & 6.926952141 & 0.009807152 \\
\hline United Kingdom & 1804 & $20-35$ & 533.8931404 & 3.85 & 7.142857143 & 0.006879594 \\
\hline
\end{tabular}

Table A8. Heavy vehicles segment-Final space cooling energy consumption of ships in the EU27+UK, the reference year 2019 .

\begin{tabular}{|c|c|c|c|}
\hline Country & $\begin{array}{c}\mathbf{n}^{\circ} \text { of Ships by } \\
\text { Operational Flags }\end{array}$ & $\begin{array}{l}\text { AHU Units System } \\
\text { Capacity }[\mathrm{kW}]\end{array}$ & FEC [TWh] \\
\hline Austria & 13 & 392 & 0.00041392 \\
\hline Belgium & 357 & 392 & 0.01136688 \\
\hline Bulgaria & 73 & 392 & 0.00232432 \\
\hline Croatia & 87 & 392 & 0.00277008 \\
\hline Cyprus & 311 & 392 & 0.00990224 \\
\hline Czechia & NA & 392 & NA \\
\hline Denmark & 928 & 392 & 0.02954752 \\
\hline Estonia & 87 & 392 & 0.00277008 \\
\hline Finland & 151 & 392 & 0.00480784 \\
\hline France & 903 & 392 & 0.02875152 \\
\hline Germany & 2395 & 392 & 0.0762568 \\
\hline Greece & 4705 & 392 & 0.1498072 \\
\hline Hungary & NA & 392 & NA \\
\hline Ireland & 114 & 392 & 0.00362976 \\
\hline Italy & 651 & 392 & 0.02072784 \\
\hline Latvia & 77 & 392 & 0.00245168 \\
\hline Lithuania & 53 & 392 & 0.00168752 \\
\hline Luxembourg & 19 & 392 & 0.00060496 \\
\hline Malta & 71 & 392 & 0.00226064 \\
\hline Netherlands & 1207 & 392 & 0.03843088 \\
\hline Poland & 130 & 392 & 0.0041392 \\
\hline Portugal & 57 & 392 & 0.00181488 \\
\hline Romania & 111 & 392 & 0.00353424 \\
\hline Slovakia & NA & 392 & NA \\
\hline Slovenia & 2 & 392 & 0.00006368 \\
\hline Spain & 224 & 392 & 0.00713216 \\
\hline Sweden & 298 & 392 & 0.00948832 \\
\hline United Kingdom & 1348 & 392 & 0.04292032 \\
\hline
\end{tabular}

\section{References}

1. European Commission L 328. Off. J. Eur. Union 2018, 61, 1-230.

2. European Commission. European Commission Report from the Commission to the European Parliament and the Council; European Commission: Brussels, Belgium, 2019.

3. Energy Efficiency Targets. Available online: https://ec.europa.eu/energy/topics/energy-efficiency/targets-directive-and-rules/ eu-targets-energy-efficiency_en (accessed on 12 October 2020).

4. European Commission 2020 Climate \& Energy Package. Available online: https://ec.europa.eu/clima/policies/strategies/2020 _en (accessed on 12 October 2020).

5. European Parliament. Report on the Proposal for a Directive of the European Parliament and of the Council on the Promotion of the Use of Energy from Renewable Sources; European Parliament: Brussels, Belgium, 2019.

6. Primary Energy Consumption. Available online: https://ec.europa.eu/eurostat/databrowser/view/t2020_33/default/table? lang=en (accessed on 13 October 2020).

7. Pezzutto, S.; Fazeli, R.; De Felice, M.; Sparber, W. Future development of the air-conditioning market in Europe: An outlook until 2020. Wiley Interdiscip. Rev. Energy Environ. 2016, 5, 649-669. [CrossRef]

8. NASA National Aereonautics and Space Administration. Available online: https://www.grc.nasa.gov/www/k-12/airplane/ thermo2.html (accessed on 23 September 2021). 
9. European Commission Commission Regulation (EU) 2016/2281 of 30 November 2016 implementing Directive 2009/125/EC of the European Parliament and of the Council establishing a framework for the setting of ecodesign requirements for energy-related products, with regard to ecodes. Off. J. Eur. Union 2016, L, 1-50.

10. Pezzutto, S. Analysis of the space heating and cooling market in Europe. Int. J. Contemp. Energy 2014, 2, 1-3.

11. Pezzutto, A.S.; Sparber, W.; Fedrizzi, R. Analysis of the space heating and cooling market in Europe. Int. J. Contemp. Energy 2020. [CrossRef]

12. The Rising Need for Cooling. Available online: http:/ / countoncooling.eu/index.php/the-rising-need-for-cooling/ (accessed on 15 October 2020).

13. Braungardt, S.; Bürger, V.; Zieger, J.; Kenkmann, T. Contribution of Renewable Cooling to the Renewable Energy Target of the EU; 2018; pp. 16-24. Available online: https://www.rvo.nl/sites/default/files/2018/07/Contribution\%20of\%20Renewable\%20Cooling\% 20to\%20the\%20Renewable\%20Energy\%20Target\%20of\%20the\%20EU.pdf (accessed on 14 December 2021).

14. Steven Brown, J.; Domanski, P.A. Review of alternative cooling technologies. Appl. Therm. Eng. 2014, 64, 252-262. [CrossRef]

15. Eurovent Market Intelligence. Available online: https://www.eurovent-marketintelligence.eu/ (accessed on 15 October 2020).

16. Pezzutto, S. Analysis of the Space Heating and Cooling Market in Europe; Universität f. Bodenkultur Wien: Vienna, Austria, 2014.

17. European Centre for Medium-Range Weather Forecasts ECMWF. Available online: https://www.ecmwf.int/en/forecasts/ datasets (accessed on 14 December 2021).

18. Commission, E. EUROSTAT-Database. Available online: https://ec.europa.eu/eurostat/databrowser/view/TRAN_R_VEHST_ custom_1299978/default/table?lang=en (accessed on 23 September 2021).

19. Unece Statistical Database. Available online: https://w3.unece.org/PXWeb2015/pxweb/en/STAT/STAT_40-TRTRANS_02_ TRROADREGRESSION (accessed on 23 September 2021).

20. International Air Transport Association. World Air Transport Statistics; International Air Transport Association: Geneva, Switzerland, 2020. Available online: https:/ / valordaaviacao.org.br/wp-content/uploads/2020/12/World-Air-Transport-Statistics-20 20.pdf. (accessed on 14 December 2021)ISBN 9789292641214.

21. Energy Plus Weather Data by Region. Available online: https:/ / energyplus.net/weather-region/europe_wmo_region_6 (accessed on 14 December 2021).

22. Association, E.A.M. ACEA Report Vehicle in Use Europe; International Air Transport Association: Geneva, Switzerland, 2019. Available online: https://www.acea.auto/files/ACEA_Report_Vehicles_in_use-Europe_2019-1.pdf. (accessed on 14 December 2021).

23. ICCT Europe European Vehicle Market Statistics. 2019. Available online: https://theicct.org/publication/european-vehiclemarket-statistics-2019-2020/ (accessed on 14 December 2021).

24. European Commission. Transport in the European Union: Current Trends and Issues; European Union: Brussels, Belgium, 2018. Available online: https://www.eca.europa.eu/Lists/ECADocuments/LR_TRANSPORT/LR_TRANSPORT_EN.pdf (accessed on 14 December 2021).

25. CEMA European Agricultural Machinery Association Stable Year for Tractor Registrations in 2019; European Agricultural Machinery Association: Brussels, Belgium, 2020; Volume 32, p. 6. Available online: https:/ / cema-agri.org/index.php?option=com_content\& view $=$ article\&id=623:stable-year-for-tractor-registrations-in-2020\&catid=18\&Itemid=215 (accessed on 14 December 2021).

26. Johnson, V.H. Fuel used for vehicle air conditioning: A state-by-state thermal comfort-based approach. SAE Tech. Pap. 2002. [CrossRef]

27. Farrington, R.; Rugh, J. Impact of Vehicle Air-Conditioning on Fuel Economy, Tailpipe Emissions, and Electric Vehicle Range; US Government: Washington, DC, USA, 2000. Available online: https://www.nrel.gov/docs/fy00osti/28960.pdf (accessed on 19 November 2020).

28. Vaghela, J.K.; Kapadia, R.G. The load calculation of automobile air conditioning system. Int. J. Eng. Dev. Res. $2014,2,97-109$.

29. Paffumi, E.; De Gennaro, M.; Martini, G. European-wide study on big data for supporting road transport policy. Case Stud. Transp. Policy 2018, 6, 785-802. [CrossRef]

30. Weng, C.L.; Kau, L.J. Design and implementation of a low-energy-consumption air-conditioning control system for smart vehicle J. Healthc. Eng. 2019, 2019, 3858560. [CrossRef]

31. Özkan, T.; Lajunen, T.; Chliaoutakis, J.E.; Parker, D.; Summala, H. Cross-cultural differences in driving behaviours: A comparison of six countries. Transp. Res. Part F Traffic Psychol. Behav. 2006, 9, 227-242. [CrossRef]

32. Zulkifli, A.A.; Dahlan, A.A.; Zulkifli, A.H.; Nasution, H.; Aziz, A.A.; Perang, M.R.M.; Jamil, H.M.; Misseri, M.N. Impact of the electric compressor for automotive air conditioning system on fuel consumption and performance analysis. IOP Conf. Ser. Mater. Sci. Eng. 2015, 100, 012028. [CrossRef]

33. Jong, D. Values of travel time in Europe: Review and Meta-Analysis. Transp. Res. Part A Policy Pract. 2016, 94, $93-111$.

34. Mebarki, B.; Draoui, B.; Allaou, B.; Rahmani, L.; Benachour, E. Impact of the air-conditioning system on the power consumption of an electric vehicle powered by lithium-ion battery. Model. Simul. Eng. 2013, 2013, 26. [CrossRef]

35. Achaichia, N.; Marta, S.R. Low Gwp Refrigerant for Buses and Trains Air Conditioning. Trains 2011, 21-24. Available online: https:/ /www.honeywell-refrigerants.com/europe/wp-content/uploads/2013/03/honeywell-solstice-hfo1234yf-lgwpbuses-trains-air-conditioning-paper.pdf (accessed on 14 December 2021).

36. Santos, A.P.P.; Andrade, C.R.; Zaparoli, E.L. A thermodynamic study of air cycle machine for aeronautical applications. Int. J. Thermodyn. 2014, 17, 117-126. [CrossRef] 
37. Pezzutto, S.; Croce, S.; Zambotti, S.; Kranzl, L.; Novelli, A.; Zambelli, P. Assessment of the space heating and domestic hot water market in Europe-open data and results. Energies 2019, 12, 1760. [CrossRef]

38. de Negri, J.F.; Pezzutto, S.; Gantioler, S.; Moser, D.; Sparber, W. A comprehensive analysis of public and private funding for photovoltaics research and development in the European Union, Norway, and Turkey. Energies 2020, 13, 2743. [CrossRef]

39. Spandagos, C.; $\mathrm{Ng}$, T.L. Equivalent full-load hours for assessing climate change impact on building cooling and heating energy consumption in large Asian cities. Appl. Energy 2017, 189, 352-368. [CrossRef]

40. Meteotest Meteonorm Software Worldwide Irradiation Data. Available online: https://meteonorm.com/en/ (accessed on 18 October 2021).

41. Programme, C. Copernicus Europe's Eyes on Earth. Available online: https://www.copernicus.eu/en (accessed on 18 October 2021).

42. Vinnova H2020 Visualization. Available online: https:/ /h2020viz.vinnova.se/\#/ (accessed on 19 November 2020).

43. Eurostat Heating and Cooling Degree Days-Statistics. Available online: https://ec.europa.eu/eurostat/statistics-explained/ index.php?title=Heating_and_cooling_degree_days_-_statistics (accessed on 19 November 2020).

44. Zhang, T.(T.); Li, P.; Wang, S. A personal air distribution system with air terminals embedded in chair armrests on commercial airplanes. Build. Environ. 2012, 47, 89-99. [CrossRef]

45. CNN Travel 2018. Available online: https://edition.cnn.com/travel/article/2018-year-in-aviation/index.html (accessed on 19 November 2020).

46. Statistics, E. Stock of Vehicles by Category and NUTS 2 Regions. Available online: https:/ / ec.europa.eu/eurostat/databrowser/ view/TRAN_R_VEHST_custom_1300883/default/table?lang=en (accessed on 19 October 2021).

47. Product Catalog Air-Conditioning Solutions Table of Contents; Webasto: Gilching, Germany, 2021; Available online: https:// www.webasto.com/fileadmin/webasto_files/documents/international/hd/catalogues/heavy-duty-catalogue.pdf (accessed on 14 December 2021).

48. Knoema Number of Locomotives and Railcars, by Source of Power. Available online: https://knoema.com/rail_eq_locon-201902 28/number-of-locomotives-and-railcars-by-source-of-power (accessed on 19 October 2021).

49. IHS IHS Markit Standard Store. Available online: https:/ / global.ihs.com/ (accessed on 19 October 2021).

50. GOV.UK Shipping Fleet Statistics: Data Tables (FLE). Available online: https://www.gov.uk/government/statistical-data-sets/ shipping-fleet-statistics\#world-fleet-registered-vessels-fle05 (accessed on 19 October 2021).

51. Statistics, E. Commercial Aircraft Fleet by Age of Aircraft. Available online: http://appsso.eurostat.ec.europa.eu/nui/ show.do?query=BOOKMARK_DS-054094_QID_605830EE_UID_-3F171EB0\&layout=AGE,L,X,0;GEO,L,Y,0;TIME,C,Z,0; INDICATORS,C,Z,1;\&zSelection=DS-054094TIME,2015;DS-054094INDICATORS,OBS_FLAG;\&rankName1=INDICATORS_1_ 2_-1_2\&rankName2 (accessed on 20 October 2021).

52. King, T. HVAC Units for Tramways; Ingersoll-Rand Company: New York, NY, USA, 2008; Volume 6, Available online: https:/ /www swisclima.ch/files/thermoking/pdf/TK60220_RAIL_HVAC_PASSENGER_(2008-09)_EN.pdf (accessed on 14 December 2021).

53. Lugo-Villalba, R.A.; Álvarez Guerra, M.; Sarria López, B. Calculation of marine air conditioning systems based on energy savings. Cienc. Tecnol. Buques 2017, 11, 103. [CrossRef]

54. Engelking, S.; Kruse, H. Development of Air Cycle Technology for Transport Refrigeration; Purdue University: West Lafayette, IN, USA, 1996; pp. 348-356. Available online: https://docs.lib.purdue.edu/cgi/viewcontent.cgi?article=1347\&context=iracc (accessed on 14 December 2021)

55. Al-Garni, A.Z.; Tozan, M.; Al-Garni, A.M.; Jamal, A. Failure forecasting of aircraft air-conditioning/cooling pack with field data. J. Aircr. 2007, 44, 996-1002. [CrossRef]

56. Dittmann, F.; Rivière, P.; Stabat, P. Space Cooling Technology in Europe; Heat Roadmap Europe: Brussels, Belgium, 2017.

57. EU. EU Regulation No. 626/2011-Energy Labelling of Air Conditioners; European Union: Brussels, Belgium, $2011 ;$ pp. 1-72.

58. European Commission Commission Regulation (EU) No 206/2012 of 6 March 2012 implementing Directive 2009/125/EC of the European Parliament and of the Council with regard to ecodesign requirements for air conditioners and comfort fans. Off. J. Eur. Union 2012, L, 7-27.

59. EU Commission Regulation (EU) 2016/2281 of 30 November 2016 Implementing Directive 2009/125/EC of the European Parliament and of the Council establishing a Framework for the Setting of Ecodesign Requirements for Energy-Related Products, with Regard to Ecodes. Available online: http://data.europa.eu/eli/reg/2016/2281/oj/eng (accessed on 18 December 2020).

60. Pezzutto, S.; Novelli, A.; Zambito, A.; Quaglini, G.; Miraglio, P.; Belleri, A.; Bottecchia, L.; Gantioler, S.; Moser, D.; Riviere, P.; et al. Cooling Technologies Overview and Market Shares; European Union: Brussels, Belgium, 2021; Available online: https: / / etendering. ted.europa.eu/cft/cft-display.html?cftId=4201 (accessed on 14 December 2021). 